\title{
Can small-scale commercial and subsistence fisheries co-exist? Lessons from an indigenous community in northern Manitoba, Canada
}

\author{
Durdana Islam* and Fikret Berkes
}

* Correspondence:

durdanaislam@gmail.com

Natural Resources Institute, University of Manitoba, 70 Dysart Road, Winnipeg, MB R3T 2M6, Canada

\begin{abstract}
Subsistence (or food) fisheries are under-studied, and the interaction between subsistence and commercial fisheries have not been studied systematically. Addressing this gap is the main contribution of the present paper, which focuses on how to deal with the challenge of overlapping commercial and subsistence fisheries. The study was conducted in Norway House Cree Nation, with qualitative data collection and questionnaire surveys. Commercial fishing in Norway House takes place during spring/summer and fall seasons, whereas subsistence fishing takes place throughout the year. Commercial fishing mostly occurs in the open waters of Lake Winnipeg; subsistence fishing in rivers adjacent to the reserve and in smaller lakes inland. How do fishers and the community deal with overlaps and potential conflicts between the two kinds of fisheries? The main mechanism is the separation of the two temporally and spatially. In the remaining overlap areas, conflict resolution relies on monitoring of net ownership and informal communication. The first mechanism is regulatory but really de facto co-management in the way it is implemented. The second is consistent with Cree cultural values of respect, reciprocity and tolerance.
\end{abstract}

Keywords: Canada, Commercial fishing, Conflict resolution, Indigenous peoples, Subsistence fishing

\section{Introduction}

Fishing is not only a livelihood but also a means of acquiring food for many people in various parts of the world. Small-scale fisheries make multiple contributions to local economies, society and culture (Weeratunge et al. 2014; Jentoft 2014), and may be pursued with multiple objectives (Nunan 2010, 2014). However, small-scale fisheries are not monolithic and may include both commercial and subsistence components (Sowman and Cardoso 2010; Berkes 2015). Commercial fishers and subsistence fishers may in some areas be depending on the same natural resource base. There can be conflicts if both kinds of fisheries exist in the same area or community. For example, commercial fisheries may overexploit the resource base, or commercial fishers' gear may intercept fish runs toward subsistence fishing areas (Ommer and team 2007). How can such conflicts be resolved? This article tries to address these challenges when

(c) 2016 Islam and Berkes. Open Access This article is distributed under the terms of the Creative Commons Attribution 4.0 International License (http://creativecommons.org/licenses/by/4.0/), which permits unrestricted use, distribution, and reproduction in any medium, provided you give appropriate credit to the original author(s) and the source, provide a link to the Creative Commons license, and indicate if changes were made. 
commercial and subsistence fisheries overlap and it becomes necessary to deal with potential conflicts.

Subsistence fisheries exist in many parts of the world but are understudied (Berkes 1990; Zeller et al. 2014). In particular inland subsistence fisheries tend to be ignored and do not get as much attention as do marine fisheries (Cooke and Murchie 2015). Global fisheries data available from the FAO underestimates the contribution of subsistence fisheries and small-scale fisheries in general (Bartley et al. 2015; Pauly 2014; Harper and Zeller 2011; Lingard et al. 2011). FAO statistics are based on official landings, and often do not reliably account for fish harvests that do not enter market mechanisms. A system based on the commercial value of the catch underestimates the real value of subsistence fisheries and their role in local and regional economies (Pauly 2014; Bartley et al. 2015). In terms of research and management, subsistence fisheries are in a disadvantageous position, as financial resources are often allocated largely on the basis of the commercial value of landed fish (Penn and Weinstein 2003). The literature of subsistence fishing is scarce and limited to few geographic areas such as South Africa (Branch 2002; Sowman 2006; Napier et al. 2005; Cockcroft et al. 2002), Australia (Barber et al. 2015; Busilacchi et al. 2013; Russell et al. 2015; Jackson et al. 2012), and Canada (Ommer and team 2007; Harris and Millerd 2010; Berkes 2012).

Subsistence fisheries are important not only for food but also for culture. For example, fishing is considered to be part of First Nations culture in northern Manitoba and elsewhere in the Canadian North. Some Indigenous peoples in Canada are referred to as First Nations. The significance of fish to First Nations communities is exhibited by lands (reserves) set aside for the exclusive use of indigenous peoples. Reserves are almost always adjacent to good fishing areas, both inland and coastal (Tough 1996). Fishing plays an important role in bringing people together socially and culturally, for example in the celebration of First Salmon ceremony (Berkes 2015, p. 232). In many areas, fish is the most abundant and reliable subsistence resource (Berkes 1990). Even though the importance of subsistence resources are well known in the indigenous peoples food and nutrition literature, the role of subsistence fisheries is not explicitly discussed (Kuhnlein et al. 2013).

Canadian courts have established that food or subsistence fisheries of indigenous people have priority over all other uses of the resource (Harris and Millerd 2010). "Subsistence fishing" is referred in literature also as "food fishing", "domestic fishing", and "native harvesting" (Berkes 1988). Branch et al. (2002) refer to subsistence fishers as "poor people" who personally harvest marine resources as a source of food for household consumption or sell their harvest to meet the basic needs of food security, even though there are no data in the literature to show that subsistence fishers are necessarily "poor people". The number of terms used in literature regarding subsistence fisheries can create confusion (Clark et al. 2002). In this paper, we use the terms subsistence and food fishing interchangeably, and define subsistence fisheries as "local, noncommercial fisheries, oriented not primarily for recreation but for the procurement of fish for consumption of the fishers, their families and community" (Berkes 1988, p. 319). Sharing is often an important part of subsistence fishing and plays a significant role in ensuring community food security (Berkes et al. 1994).

The available literature on North America often equates subsistence fisheries with aboriginal (indigenous) fisheries, and the older literature includes detailed studies from 
parts of North America, such as the Great Lakes and the Pacific Northwest (Cooke and Murchie 2015). Historically, indigenous subsistence fisheries were impacted by commercial fisheries (Tough 1984). In the United States Pacific Northwest (Cohen 1986) and in the adjoining Canadian Province of British Columbia, the development of commercial salmon fisheries undermined local indigenous economies (Ommer and team 2007; Trosper 2009). In the Province of Manitoba, the development of commercial fisheries, mainly for lake whitefish Coregonus clupeaformis undermined native subsistence fisheries (Tough 1984, 1996). However, under certain circumstances, commercial and subsistence fisheries can co-exist. Experience in South Africa indicates that, for coexistence to occur, commercialization of subsistence fisheries needs to be socially beneficial and the fishery managed properly (Arnason and Kashorte 2006).

In many parts of the world, for example in Manitoba, Canada, commercial and subsistence fisheries in fact do co-exist. Manitoba statistics for 2013-14, compiled by the Freshwater Fish Marketing Corporation, indicate that 30 First Nations out of a total of 63 were licensed for commercial fisheries; we assume that all or nearly all 63 have subsistence fisheries as well. This raises the question of how these two kinds of fisheries co-exist in the same area, often the fishing area of a small community. Limited published literature exists on the interaction between the two kinds of fisheries. The paper tries to address the challenge of co-existence by focusing on the mechanisms that make co-existence possible, using the case of a relatively remote First Nations community in northern Manitoba.

\section{Study area and research methods}

The study was conducted in Norway House Cree Nation, one of the largest First Nations communities in Manitoba, with a resident population of 4758 in 2011 (Statistics Canada 2013). Norway House is situated $450 \mathrm{~km}$ north of Winnipeg, at the convergence of Lake Winnipeg and the Nelson River (Fig. 1). Norway House was an important fur trade post in the $18^{\text {th }}$ and $19^{\text {th }}$ centuries. The majority of residents are Cree, one of the largest aboriginal groups in Canada that extend across the boreal and subarctic regions from Labrador to British Columbia. Fishing is an important part of First Nations livelihoods; and Norway House is no exception, with fishers engaged in both subsistence and commercial fishing.

Norway House Fisherman's Co-op was established in 1962. The commercial fishing licences are owned and regulated by the Co-op. The Co-op has 50 active commercial fishing licences, all of them held by male fishers. The Co-op also has two inactive licences. If a commercial fisher is inactive for two consecutive years, his licence becomes vacant. Commercial fishers renew their fishing licences every year by paying a small renewal fee to the Manitoba Department of Conservation and Water Stewardship. It is by law in Manitoba that commercial fishers have to sell their commercial catches to Fresh Water Fish Marketing Corporation, and Norway House fishers do this through their Co-op.

In the study area, only three species are quota fish, managed under quantitative harvest limits: walleye, Sander vitreus (locally called pickerel), sauger, Sander canadensis, and lake whitefish (including lake herring, Coregonus artedii), and these quotas are controlled by the Co-op. During the fishing season, a commercial fisher is only allowed to bring 20 tubs (one tub is about $27 \mathrm{~kg}$ ) of quota fish per day and unlimited tubs of non-quota fish. Commercial fishing occurs in three places: Lake Winnipeg, Playgreen 


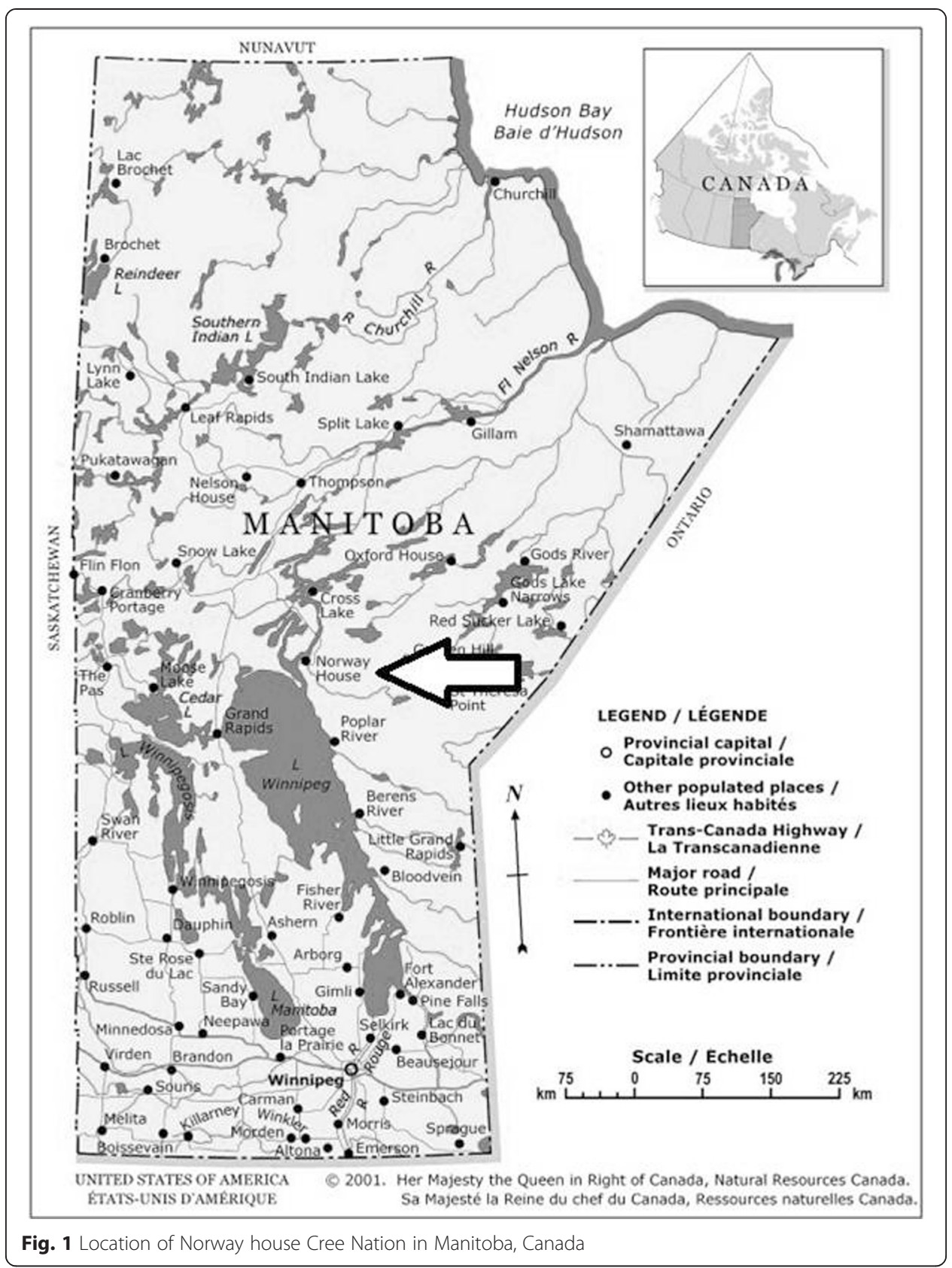

Lake and Kiskittogisu Lake. During the spring/summer season fishers can only fish in Lake Winnipeg; during fall season they can fish in all three lakes. There are different quotas allocated for these different lakes. Lake Winnipeg has the highest quota of $608,000 \mathrm{~kg}$ round weight (of which only $280,305 \mathrm{~kg}$ can be walleye and sauger), Playgreen Lake has a total quota of $115,900 \mathrm{~kg}$ round weight and Kiskittogisu Lake has a total quota of $31,000 \mathrm{~kg}$ round weight. Commercial fishers have to fulfill their quota from a specific lake before they are allowed to fish in another lake. They are not allowed to sell fish of one lake under the quota of another lake. The Co-op has two fish landing stations: Playgreen station (operates in all fishing seasons) and Whiskeyjack station (operates only in fall fishing season). 
Most members of a household, men, women and children, participate in subsistence fishing. Traditionally, fishing was a family activity. However, in recent years, the role of women in subsistence fishing has declined to low levels, according to a senior informant. People go to rivers and small lakes adjacent to the community for subsistence fishing. For those who go to hunting camps, there is also subsistence fishing in the lakes in the interior of Norway House's community harvesting area. Given the importance of fishing for the community, there is an outdoor education course in schools in Norway House for children to learn how to fish.

This study was conducted over a period of 14 months from September 2013 to November 2014. The study included commercial fishers and subsistence fishers as research participants. We also conducted interviews with the president, secretary and members of Norway House Fisherman's Co-op. This mixed-methods research study employed semi-structured interviews of key informants and focus group discussions, followed by two separate questionnaires surveys (administered to commercial fishers and subsistence fishers) and additional interviews to follow up on results of the questionnaires. Two community researchers were employed to help with questionnaire surveys. The questionnaire was pretested by fishers, Co-op members and other community members to ensure that the questions were culturally appropriate and respectful.

The questionnaire survey for commercial fishers used snowball sampling. The sample size was 35 (out of 50, or some $70 \%$ of the Co-op membership). We asked commercial fishers if they perceived any conflict between the two kinds of fisheries. An interpreter was employed to help interview senior fishers who speak only Cree. A similar but different set of questions was used for subsistence fishers. The sample size was 100 households, and the interviews were held with both men and women household heads were possible and included the harvest of all members of that household. The household questionnaire survey was conducted by a community researcher from October 2013 to March 2014. He went from door to door and conducted the survey. The sample frame included all different groups of fishers, particularly seniors, female headed-households, old peoples' home and presumed low-income households. We identified key informants by discussing with senior fishers, Co-op officials and community researchers. We conducted detailed interviews of key informants to follow up on the questionnaire results and to validate the data. During the follow up interviews we asked questions on Cree cultural values and its role on resolving conflicts between two kinds of fisheries.

We obtained statistical data on seasonal catch of commercial fishers from the Norway House Fisherman's Co-op and we conducted semi-structured interviews with the Conservation and Water Stewardship (the government regulatory body) district supervisor and his assistant to find out how they regulate commercial and subsistence fishers, for example, in making sure that commercial fishers follow the start and end dates of commercial fishing seasons, and in enforcing commercial fishing guidelines (e.g., the minimum allowable mesh size and the maximum boat size).

\section{Results: overlap between subsistence and commercial fisheries}

Questionnaire data showed a high percentage of Norway House households (77 of 100 or $77 \%$ ) participating in subsistence fishing in the year of 2012-13. We asked the head of each household to identify their fish harvesting pattern from a given list of four options. The list includes intensive harvesters (according to community members a fisher 
who brings a "lot of" fish), active harvesters (according to community members a fisher who brings "some but not a lot of" fish), occasional harvesters (according to community members a fisher who harvests fish only "occasionally") and non-harvester (who does not harvest at all). Results show that participation rate is high, but relatively few households fish intensively. About $58 \%$ of the subsistence fishing households are occasional harvesters (Fig. 2).

All commercial fishers in our sample (35 of 35) also took part in subsistence fishing. Out of 52 commercial fishers in Norway House Fisherman's Co-op, 47 were treaty (i.e., registered indigenous people) commercial fishers and five were non-treaty fishers. Treaty commercial fishers can participate in both kinds of fisheries, as subsistence fisheries is a treaty right (Fig. 3). The potential overlap (and therefore conflict) between subsistence and commercial fishing was analyzed with respect to two factors: overlap in the species harvested and overlap in the fishing gear use.

\section{Both kinds of fisheries target same fish species}

Commercial and subsistence fishers targeted similar species. In the questionnaire survey, subsistence fishers were asked to indicate their main species by season, in terms of their largest catch, medium catch and occasional catch (by weight) for the year 201213. Table 1 shows the results. In all seasons, the main species harvested was walleye, lake whitefish and northern pike, Esox lucius, locally called jackfish, were seasonally important, and the species of occasional catch varied from season to season.

Walleye is also the commercially most significant species, followed by lake whitefish, northern pike and white sucker. In fact, every single fish species that occurs in the subsistence list (Table 1) also occurs in the commercial list (Table 2) with the exception of burbot. This latter species is only harvested for subsistence purposes during the winter season. The liver of burbot is considered as a delicacy for First Nations people, and presumably important for nutrition in winter, as burbot is a freshwater cod and the liver is

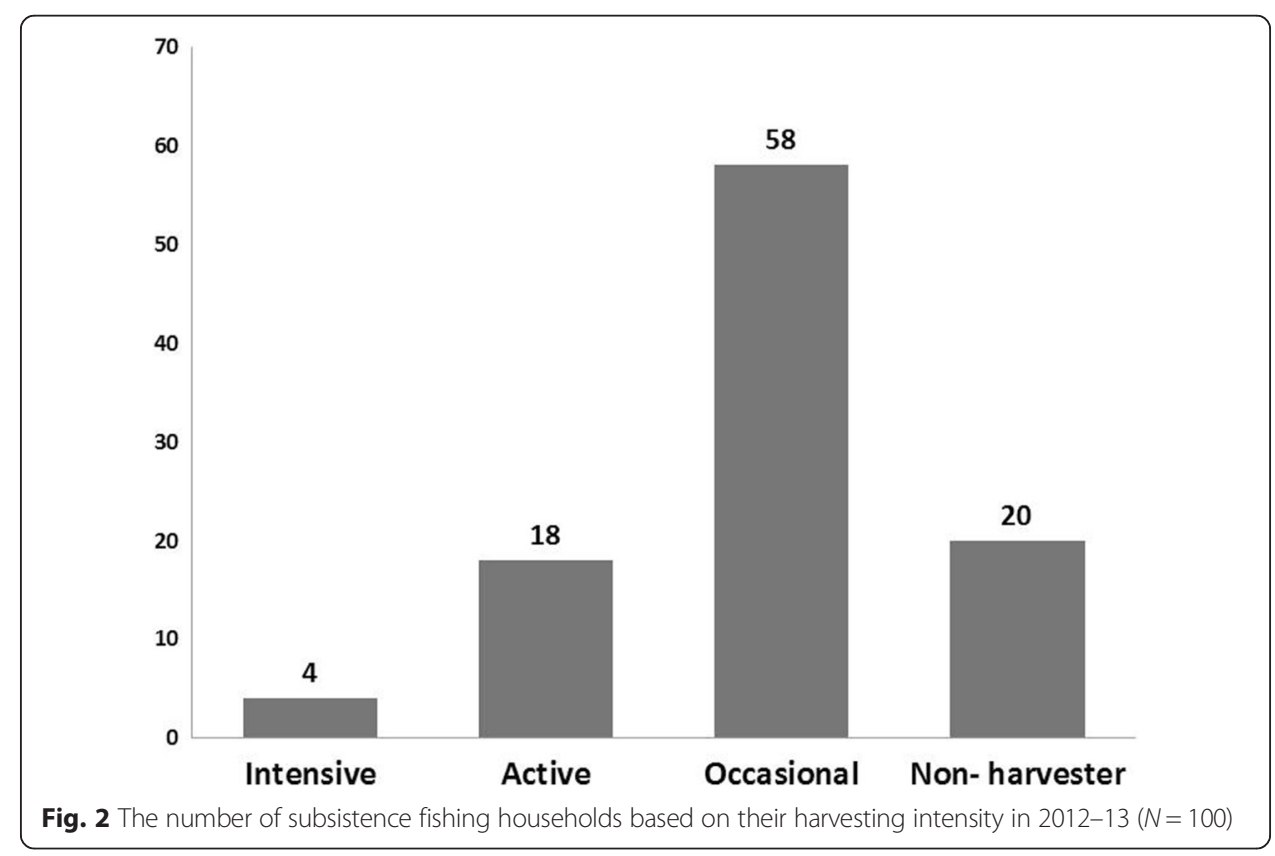




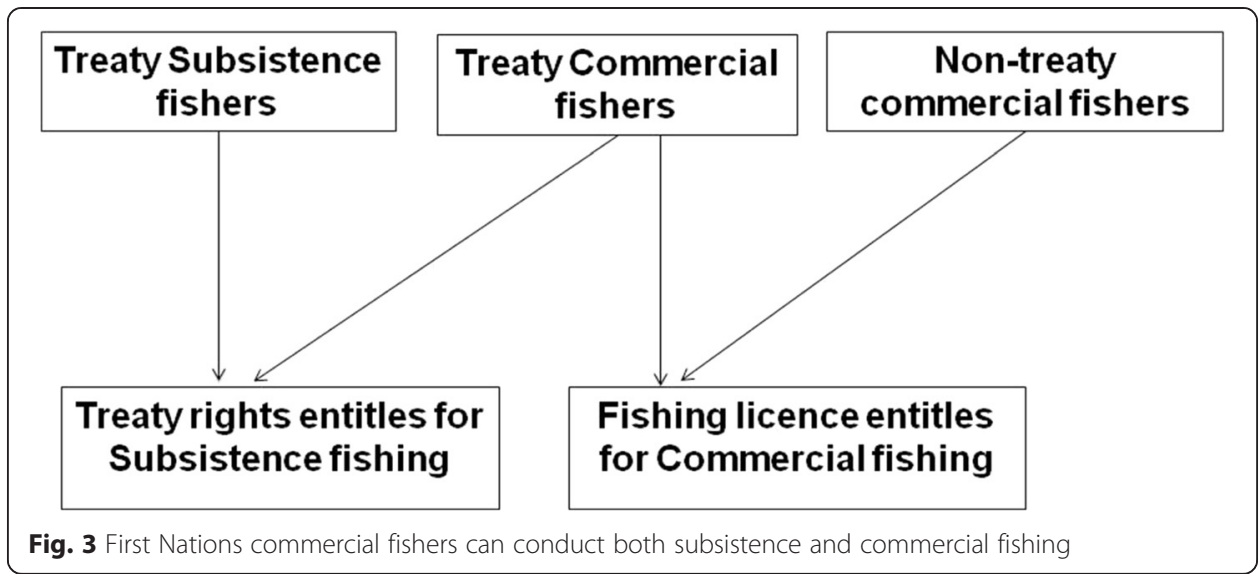

rich in vitamin D ("cod liver oil"). According to informants, burbot was very popular in the past and it is still popular among elders in the community but not among the younger generations.

\section{Both kinds of fisheries use similar fishing gear}

Commercial fishers usually use gill nets from open boats to catch all commercial species. They cannot have more than $1400 \mathrm{~m}$ of fishing net in the water at one time which means they are only allowed 15 nets at a time. Subsistence fishers typically use one or two nets, but there is no legal restriction on the number of nets as long as the catch is used for personal and household consumption. In Norway House, as elsewhere in the Canadian subarctic and boreal zone (Berkes 1977; Berkes et al. 1994), most subsistence fishing used to be carried out by the use of gill nets, supplemented by set lines and rod-and-reel fishing, with fish traps and seining, as appropriate for an area. However, the imported technique of rod-and-reel fishing has become increasingly more important; as it is cheaper compared to gill nets to purchase and easier to use. According to a knowledgeable informant, the use of gillnets in Norway House has declined mainly due to increasing cost of gas as one needs a boat to use gillnets for fishing, and probably more than half of the subsistence fishing is done by rod-and-reel.

There are a number of differences in the equipment used and applicable regulations for the two kinds of fisheries. According to questionnaire data, $57 \%$ of commercial fishers used fiberglass boats and the rest aluminum boats. These boats were usually equipped with two $120 \mathrm{HP}$ engines for speed and safety. Subsistence fishers use a variety of boats including paddle canoes and canoes with engines (mostly less powerful). Commercial fishers can use various mesh sizes but not smaller than 4.25 in. (108 mm) as specified in their fishing licences. For subsistence fishers there is no restriction on

Table 1 Species harvested by subsistence fishers at Norway House in 2012-13

\begin{tabular}{llll}
\hline Seasons & Largest catch & Medium catch & Occasional catch \\
\cline { 3 - 4 } Summer/Fall & Walleye & Lake whitefish & $\begin{array}{l}\text { Whitefish, sauger, northern pike and white sucker } \\
\text { (Catostomus commersonii, locally called mullet) }\end{array}$ \\
Winter & Walleye & Whitefish, northern pike & $\begin{array}{l}\text { Northern pike, sauger, white sucker and burbot } \\
\text { (Lota lota, locally called mariah) }\end{array}$ \\
Spring & Walleye & Northern pike & Whitefish, northern pike
\end{tabular}


Table 2 Commercially significant fish species according to catch and sale records of Norway House Fisherman's Co-op in the year 2012-13

\begin{tabular}{lll}
\hline Rank & Species & Percent of total revenue \\
\hline 1 & Walleye including sauger & 51 \\
2 & Lake whitefish including lake herring & 44 \\
3 & Northern pike & 3 \\
4 & White sucker & 1 \\
5 & Other & 1 \\
\hline
\end{tabular}

mesh size. Commercial fishers are not allowed to fish in rivers or within $1.5 \mathrm{~km}$ of river mouths (to protect spawners and spawning areas). Subsistence fishers do not have such restrictions and they can put nets anywhere, as long as the area is not closed for conservation purposes.

In summary, both commercial and subsistence fisheries target the same species and use similar fishing gears (gillnets) but the subsistence fishery increasingly uses rod-andreel as well. However, the two kinds of fishing differ in terms of the scale of operations: small number (50) of commercial fishers harvesting intensively vs. large number (some 1800, assuming two fishers per active household) of subsistence fishers fishing sporadically and lightly. Based on survey results, $77 \%$ of households participate in the subsistence fishery, that is, some $610-620$ out of a total of about 800 households, assuming 4758 residents and six persons per household. (Exact numbers are not available due to seasonal movements of families in and out of the community.) However, these large numbers of subsistence fishers fish a few locations only a few days of the year. Table 3 shows the number of households $(\mathrm{N}=100)$ participating in subsistence fishing by season in 2012-13.

The two kinds of fisheries also differ in the size of boats and engines used and the applicable regulations. Nevertheless, it is clear that there is substantial overlap between the two kinds of fisheries. How do the fishers and the community of Norway House deal with the potential conflicts, such as damaging one another's gear or blocking fish movements?

\section{Dealing with potential conflicts between subsistence and commercial fishing}

In Norway House, the potential conflict between the two kinds of fisheries is handled by temporal and spatial separation of the two. Temporal separation refers to the segregation of the two fisheries temporally, with the two fisheries taking place in different times of the year. Spatial separation refers to fisheries taking place in different geographical locations within the community's fishing area. These two measures provide separation but not absolute separation, requiring some additional arrangements to

Table 3 About how many days did you spend subsistence fishing during the year 2012-13?

\begin{tabular}{llll}
\hline Number of days & $\begin{array}{l}\text { Number of subsistence fishers } \\
\text { fishing in Summer/Fall }\end{array}$ & $\begin{array}{l}\text { Number of subsistence fishers } \\
\text { fishing in Winter season }\end{array}$ & $\begin{array}{l}\text { Number of subsistence fishers } \\
\text { fishing in Spring Season }\end{array}$ \\
\hline $1-5$ days & 21 & 13 & 25 \\
$5-15$ days & 31 & 10 & 31 \\
$15-45$ days & 4 & 3 & 8 \\
Over 45 days & 7 & 2 & 5 \\
\hline
\end{tabular}


avoid potential conflicts. These include monitoring of net ownership and informal negotiation and communication.

\section{Temporal separation}

We interviewed community members and asked if they perceived a conflict between commercial and subsistence fisheries. No one perceived a conflict between the two, and many commented on the complementarity of the two.

There is no conflict. We don't have commercial fishing three weeks in summer and 3 weeks in the fall. We can pretty much harvest domestic fish in between commercial fishing seasons. During commercial fishing season, if people ask for fish, we usually give it to them. We share our catches. If I am done my quota [reached the legal catch limit] and I have extra walleyes, I will usually give it to somebody whose asking for it or [someone] I know hasn't eaten fish for a while-Commercial fisher A, personal communication, January 2014.

Commercial fishing in Norway House takes place during spring/summer and fall seasons. Spring/summer commercial fishing lasts for 5 weeks and fall commercial fishing lasts for 6 weeks. In total, commercial fishing is carried out over 11 weeks of the year. Commercial fishing does not take place in winter. However, subsistence fishing takes place throughout the year, including the winter season.

\section{Spatial separation}

In our domestic fishing areas, we cannot do commercial fishing as we do not get enough volume of fish. The domestic fishing areas are mostly in the rivers, and the commercial fishing areas are in the lake where there are deeper and more water.Commercial fisher B, personal communication, March 2014.

Commercial fishing occurs mostly in the open waters of Lake Winnipeg where commercial fishers can obtain large catches of walleye and lake whitefish, the two species that are economically most profitable. During fall fishing season, commercial fishers can fish in Lake Winnipeg, as well as in the smaller Playgreen and Kiskittogiso lakes; however during spring/summer season they can only fish in Lake Winnipeg. Commercial fishers first fish in Lake Winnipeg, as it is more profitable to fish there, and the Fisherman's Co-op monitors the fish coming into the station. After the quota is filled in Lake Winnipeg, Coop then opens Playgreen Lake for fishing. Subsistence fishing occurs mainly in rivers, small lakes adjacent to the community, and in lakes in the interior to the north and northeast of the community. It does not take place in the open waters of Lake Winnipeg. Subsistence fishers were asked to list the areas where they go for food fishing. The areas included Playgreen Lake, Little Playgreen Lake, Blackwater, Jam Rapids, Paimusk Creek, Molson Lake, Spider Lake, and Whiskeyjack. All of these are non-commercial water bodies (with the exception of Playgreen Lake) or lakes in the interior.

Playgreen is the only place where I do domestic and commercial fishing. There is never really a conflict... There [are] lot of places to fish and not too many people go 
out to Lake Winnipeg to do domestic fishing. They usually do it in rivers around their area or close by rivers-Commercial fisher A, personal communication, March 2014.

There is evidence that spatial separation has been evolving over the years to reduce conflicts. According to a senior fisher, there used to be conflict between the two kinds of fisheries around 20 years ago when subsistence fishing was not allowed in Playgreen Lake, and both kinds of fishing took place in Lake Winnipeg. This is not the case any longer. Further, the current distributions of the two kinds of fisheries seem to suit local preferences. Many subsistence fishers prefer non-commercial areas, and many would agree with the following comment that river fish taste better.

People say there is a difference between Lake Winnipeg fish and river fish. I also think they are different in taste and size. [That is because] fish from river are smaller and the ones in the Lake are larger. Tastewise, river fish do not have that fishy odor [and] taste. The smaller the fish, it tastes better. Lake fish is bigger in size and has a fishy taste. River fish is smaller in size and does not have a fishy taste. River fish tastes better than lake fish.-Commercial fisher B, personal communication, March 2014.

Although commercial and subsistence fisheries are separated to a large extent temporally and spatially, there are places where overlap occurs between the two (Fig. 4). These are the two relatively small lakes near the community, namely Playgreen Lake (with 45 commercial fishers in the 2014 summer/fall season) and Kiskittogiso Lake (11 commercial fishers), according to data from the Manitoba Department of Conservation and Water Stewardship. It is these two areas that require additional arrangements for the resolution of potential conflicts.

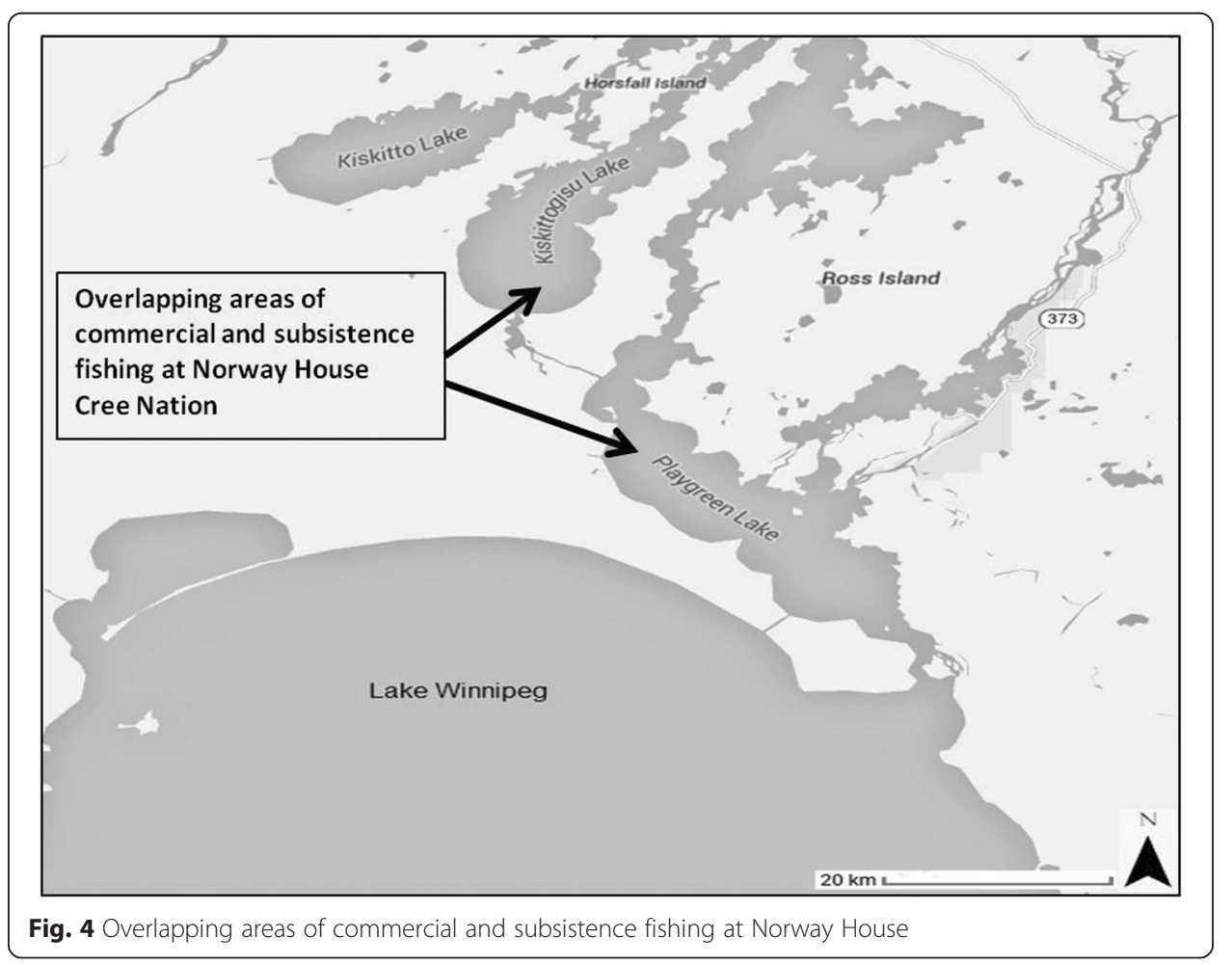




\section{Monitoring of net ownership}

To enforce regulations, the provincial conservation officer teams up with an assistant officer who is a senior member of Norway House, well respected in the community by other fishers and community members. The officer takes an educational approach in dealing with rule enforcement, which includes creating awareness about fishing regulations. At the beginning of each fishing season, the conservation office puts announcements in the local radio to remind fishers to tag their nets. All nets need to be tagged in order to establish the authority under which the net is set. Every First Nation member has a treaty number; by law, every subsistence fisher has to tag his net with his name and unique treaty number. And every commercial fisher has to tag his net with his commercial licence number. When conservation officers find a net that is not tagged, they first put their cards as a warning. According to the officers, in recent years they have not had to lay charges or fine anyone, as the informal warning seems to be effective.

According to conservation officers, in the recent past there has not been any conflict between subsistence and commercial fishers in the community. The ease of monitoring net ownership has probably been a factor in this, as it helps conservation officers detect any commercial fishing nets set in non-commercial fishing areas such as rivers. The prevailing net monitoring system also makes it easier for conservation officers to track any discrepancies in commercial landings vs. quotas by lake, discouraging commercial fishers from setting nets in areas that they should not be fishing and generally keeping the two kinds of fishing separate.

\section{Informal negotiation and communication}

Even though the two fisheries are separated by the mechanisms described above, there are nevertheless some possibilities for conflict, as for example, a subsistence fisher setting nets in the commercial fishing area. This kind of problem tends to be resolved by informal negotiation and communication, consistent with Cree cultural values of mutual tolerance, respect and reciprocity. For example, an old fisher with a single net in a commercial area is tolerated. As well, there are some customary sites for specific families or senior subsistence fishers, and other parties mutually respect that. For example, older people go to Nelson River for subsistence fishing and younger fishers respect their fishing areas and fish elsewhere to avoid conflict.

Most of the domestic fishing happens along the rivers here in Norway House. Older people will go down the bank to put their net and they also put their treaty number on their marking. As long as they are not covering the whole river [and blocking fish passage] it is ok. Nelson River is the place where most of the older people go for fishing. We usually know who they are because when we drive our boats, we see the person with their nets. So word of mouth goes around pretty fast that 'so and so' is fishing in this area. People usually know that this fellow usually puts their net in this place.-Subsistence fisher B, personal communication, March 2014.

Much of this informal communication for resource allocation is part of the selfmanagement of subsistence fisheries, whereby different fishers or different groups of fishers solve their own problems through communication and negotiation (Berkes 
1977; Berkes 2012). The fact that the customary practice is backed up by government regulation and enforcement helps maintain good social relations. The presence of the assistant conservation officer, a respected member of Norway House community, is an important factor in this equation.

\section{Discussion and conclusions}

Both subsistence and commercial fisheries are important: the commercial fishery brings cash income, and the subsistence fishery provides food for local consumption. Both kinds of fishing may be contributing to food security either directly or indirectly through the purchase of other food from commercial fishing income (Sen 1981). In Norway House, both kinds of fisheries do contribute to food security (Islam and Berkes, 2016). Food security is a large topic in its own right, and is not dealt with in the present paper. Managing small-scale fisheries for food security is likely to become increasingly important (McClanahan et al. 2015). This is specially so considering that even in middle income countries such as Brazil, small-scale fisheries provide more human food than do large-scale fisheries (Begossi 2010). Further, the global significance of subsistence fisheries for food security is increasingly recognized (Branch 2002; Sowman 2006; Pauly 2014). In the case of Norway House, for example, both subsistence and commercial fishers share their catches with other households and contribute to food security at the community level.

In Southern Africa, many small-scale fisheries have a subsistence component in the sense that a part of the catch is diverted to household and community needs, such as local food and income (Sowman 2006; Béné et al. 2007). Globally, inland capture fisheries, and its subsistence component, are underestimated. This is because much of the harvest is for local food and local and regional trade, and none formally enters the market economy (Béné et al. 2007; HLPE 2014; Bartley et al. 2015). However, commercial and subsistence fisheries are treated as distinct if they come under different sets of government regulations. Such is the case in Canada's indigenous fisheries (Harris and Millerd 2010). The rules that apply to commercial fisheries do not apply to food fishing, which is an indigenous right, subject to conservation considerations. However, if the two kinds of fisheries take place in the same area, there is potential for conflict, a topic that does not seem to have been addressed in the literature to any extent.

This gap in the literature was addressed here by examining the case of Norway House Cree Nation in northern Manitoba, at the northern tip of the tenth largest lake in the world. The commercial fishery is organized along the lines of most commercial fisheries in Canada, at sea and in large lakes, with a catch quota system, open and closed seasons, and fishing gear regulations. At Norway House, the entire fish quota is held by a 52-member fisheries co-op, which also harvests and sells non-quota species. Much larger numbers of people, catching smaller amounts of fish per capita, comprise the subsistence fishery. About three-quarters of households of this relatively large indigenous community participate in the food fishery. Subsistence fishing is an aboriginal right, and the fishery does not come under direct government regulation, except for species and areas closed for conservation reasons.

In Norway House, there appeared to be a potential for conflict because the two kinds of fisheries harvested the same species of fish, with walleye as the top commercial species as well as the most highly preferred subsistence species. Further, the two fisheries 
employed similar gear, with the commercial fishery using gillnets and the subsistence fishery using a mix of gillnets and rod-and-reel. One potential reason for lack of conflict is that northern Lake Winnipeg is a large area and the number of fishers is relatively small. However, northern lakes in Canada are low in biological productivity, and walleye stocks are fully exploited (Ayles et al. 2011).

The potential conflict between the two kinds of fisheries is resolved by a mix of mechanisms. First is the temporal separation of the two fisheries. The commercial fishery takes place over 11 weeks of the year; the subsistence fishery is year-round. A more clear-cut temporal separation is practiced in some indigenous communities in British Columbia, Canada, where separate days for subsistence and commercial fishing are in effect during the salmon season. For instance, on food fishing days, a commercial fisher with the same boat and gear (e.g., a drift net) may catch fish for subsistence purposes (Berkes, unpublished field notes).

Second, commercial and subsistence fisheries in Norway House are separated spatially, a mechanism also used in some areas in British Columbia, Canada. The commercial fishery takes place mostly in the open waters of Lake Winnipeg, whereas the subsistence fishery takes place mostly in rivers and small lakes. In two relatively small lakes, the two kinds of fisheries overlap. How then does one ensure that the commercial fishery does not impact the subsistence one, or conversely, food fishers do not get in the way of commercial fishers as they try to fill their catch quotas in the limited number of weeks available?

Two additional conflict resolution mechanisms come into play. First, the local conservation officers monitor net ownership. Commercial nets and subsistence fishing nets need to be marked with commercial fishing tags or tags bearing the name and treaty number of the subsistence fisher, respectively. The tagging system helps enforce regulations, and community members consider this monitoring and enforcement as legitimate, partly (or perhaps largely) because the conservation officer (an outsider) is accompanied by an assistant officer who is a community member. According to our interview results, this arrangement appears to be very effective. Further, both officers strongly agreed in interviews that the arrangement constitutes de facto comanagement, creating a problem-solving dialogue between government management and local management (Armitage et al. 2007). The second additional mechanism involves informal negotiation and communication, again aided by the low-cost locally effective co-management of the two conservation officers working together, solving problems as they appear without having to resort to legal charges or fines.

Understanding Cree cultural values is helpful in illuminating the workings of these additional conflict resolution mechanisms. Commercial fisheries are not a good fit with Cree values in the first place because they are production and surplus oriented. As pointed out by the President of the Fishermen's Co-op, the objective of the commercial fishery is to catch fish and make as much money as possible, in theory. In reality, however, the Co-op does not operate as an outsider organization but is very much integrated into the community. Most profits of the Co-op are reinvested in the community to promote development. For example, Fisherman's co-op runs a gas station, a timber business, a convenient store and a fast-food store which generate employment and income in Norway House. Almost all commercial fishers are also subsistence fishers at various times of the year. Perhaps most importantly, many commercial fishers share 
their harvests with other community members and contribute to the community's food security (Islam and Berkes, 2016). All of these are consistent with Cree values of sharing and using natural resources, not for individual profit, but for the well-being of the community as a whole. This makes the commercial fishery a good corporate citizen.

Subsistence fisheries operate according to the Cree cultural logic of self-sufficiency. Subsistence fishers do not have any incentives to create a surplus; extra fish they catch cannot be sold but will be given away. Consistent with Cree values of not wasting natural resources, a Cree fisher catches only as much as he/she needs (Berkes 1977). According to Cree culture, a good fisher or hunter is a person who catches what is needed, not someone who harvests a surplus above and beyond what would be needed by the family and shared with a few additional households (Feit 1978).

Informal negotiation and communication for handling conflict are also consistent with Cree cultural values of tolerance, reciprocity and respect. Small infractions are tolerated; elders are shown respect by not being contested in good fishing spots near the community. Significantly, conflict resolution by quiet communication and mutual respect are preferred over litigation and the embarrassment of charges and fines. Thus, a conservation officer who can solve problems by such civil (as opposed to confrontational) means gains social acceptance in the community. He/she will be more effective in enforcement in the long term. The lesson from the case is that government officers working with subsistence fisheries need to be tuned into the cultural values of the communities in which they work, as also pointed out by Arnason and Kashorte (2006).

Going back to the objectives of the paper, we argue that small-scale commercial and subsistence fisheries can co-exist, provided appropriate measures are taken by fishers, community members and authorities to avoid the conflict when two kinds of fisheries overlap. These measures need to be collaborative, flexible and adaptable, evolving through communication and negotiation to solve problems learning-by-doing in a step wise fashion, that is, adaptive learning (Idrobo and Davidson-Hunt 2012). They may be innovated through de facto co-management, as in the Norway House case. There likely is no single solution that is universally applicable. The lesson from Norway House is that conflicts can be avoided by temporal separation, spatial separation, formal monitoring and informal negotiation. The Conservation and Water Stewardship office in Norway House follows an educational approach in implementing regulations and eliminating conflict before it occurs. Lessons from Norway House are relevant to other indigenous communities elsewhere in Canada, and internationally where small-scale fisheries and subsistence fisheries are found to co-exist. 
Received: 27 July 2015 Accepted: 14 January 2016

Published online: 19 January 2016

\section{References}

Armitage, D., F. Berkes, and N. Doubleday. 2007. Adaptive Co-management: collaboration, learning, and multi-level governance. Vancouver: University of British Columbia Press.

Arnason, R., and M. Kashorte. 2006. Commercialization of South Africa's subsistence fisheries? considerations, criteria and approach. International Journal of Oceans and Oceanography 1: 45-65.

Ayles, G.B., K. Campbell, D. Gillis, L. Saunders, K.J. Scott, R. Tallman, and N. Traverse. 2011. Technical assessment of the status, health and sustainable harvest levels of the lake Winnipeg fisheries resource. Winnipeg: Lake Winnipeg Quota Review Task Force. https://www.gov.mb.ca/waterstewardship/fisheries/commercial/pdf/lwtf2011.pdf.

Barber, M., S. Jackson, J. Dambacher, and M. Finn. 2015. The persistence of subsistence: qualitative social-ecological modeling of indigenous aquatic hunting and gathering in tropical Australia. Ecology and Society 20(1): 60.

Bartley, D.M., G.J. De-Graaf, J. Valbo-Jorgensen, and G. Marmulla. 2015. Inland capture fisheries: status and data issues. Fisheries Management and Ecology 22: 71-77.

Begossi, A. 2010. Small-scale fisheries in Latin America: Management models and challenges. Maritime Studies 9(2): 7-31.

Béné, C., F. Macfadyen, and E.H. Alison. 2007. Increasing the contribution of small-scale fisheries to poverty alleviation and food security, FAO fisheries technical paper No. 481.

Berkes, F. 1977. Fishery resource use in a subarctic Indian community. Human Ecology 5: 289-307.

Berkes, F. 1988. Subsistence fishing in Canada: a note on terminology. Arctic 41: 319-320.

Berkes, F. 1990. Native subsistence fisheries: a synthesis of harvest studies in Canada. Arctic 43: 35-42.

Berkes, F. 2012. Sacred ecology, 3rd ed. New York and London: Routledge.

Berkes, F. 2015. Coasts for people. Interdisciplinary approaches to coastal and marine resource management. New York and London: Routledge.

Berkes, F., P.J. George, R.J. Preston, A. Hughes, J. Turner, and B.D. Cummins. 1994. Wildlife harvesting and sustainable regional native economy in the Hudson and James Bay Lowland, Ontario. Arctic 47: 350-360.

Branch, G.M. 2002. Subsistence fisheries in South africa: a preface. South African Journal of Marine Science 24: 403-404

Branch, G.M., M. Hauck, N.N. Siqwana, and A.H. Dye. 2002. Defining fishers in the South African context: subsistence, artisanal and small-scale commercial sectors. South African Journal of Marine Science 24: 475-487.

Busilacchi, S., G.R. Russ, A.J. Williams, S.G. Sutton, and G.A. Begg. 2013. The role of subsistence fishing in the hybrid economy of an Indigenous community. Marine Policy 37: 183-191.

Clark, B.M., M. Hauck, J.M. Harris, K. Salo, and E. Russell. 2002. Identification of subsistence fishers, fishing areas, resources use and activities along the South African Coast. South African Journal of Marine Science 24: 425-437.

Cockcroft, A.C., W.H.H. Sauer, G.M. Branch, B.M. Clark, A.H. Dye, and E. Russell. 2002. Assessment of resource availability and suitability for subsistence fishers in South Africa, with a review of resource management procedures. South African Journal of Marine Science 24: 489-501.

Cohen, F. 1986. Treaties on trial: the continuing controversy over Northwest Indian fishing rights. Seattle and Washington: University of Seattle Press.

Cooke, S.J., and K.J. Murchie. 2015. Status of aboriginal, commercial and recreational inland fisheries in North America: past, present and future. Fisheries Management and Ecology 22: 1-13.

Feit, H.A. 1978. Waswanipi realities and adaptations. Resource management and cognitive structure, PhD Thesis. Montreal: Dept. of Anthropology, McGill University.

Harper, S., and D. Zeller (eds.). 2011. Fisheries catch reconstructions: Islands, Part II, Fisheries centre research reports. University of British Columbia: Fisheries Centre.

Harris, D.C., and P. Millerd. 2010. Food fish, commercial fish, and fish to support a moderate livelihood: characterizing aboriginal and treaty rights to Canadian fisheries. Arctic Review on Law and Politics 1: 82-107.

HLPE. 2014. Sustainable fisheries and aquaculture for food security and nutrition, A report by the high level panel of experts on food security and nutrition of the committee on world food security. Rome: World Food Security.

Idrobo, C.J., and I.J. Davidson-Hunt. 2012. Adaptive learning, technological innovation and livelihood diversification: the adoption of pound nets in Rio de Janeiro State, Brazil. Maritime Studies 11: 3.

Islam, D, and Berkes, F. 2016. Indigenous peoples' fisheries and food security: a case from northern Canada. Food Security. Natural Resources Institute, University of Manitoba, Winnipeg.

Jackson, S, M. Finn, and P. Featherston. 2012. Aquatic resource use by indigenous Australians in two tropical river catchments: the Fitzroy River and Daly River. Human Ecology 40(6): 893-908.

Jentoft, S. 2014. Walking the talk: implementing the international voluntary guidelines for securing sustainable smallscale fisheries. Maritime Studies 13: 16.

Kuhnlein, H.V., B. Erasmus, D. Spigelski, and B. Burlingame (eds.). 2013. Indigenous Peoples' food systems and well-being: interventions \& policies for healthy communities. Rome: FAO/CINE.

Lingard, S., S. Ota, Y. Harper, and D. Zeller. 2011. Marine fisheries of Palao, 1950-2008: Total reconstructed catch. In Fisheries catch reconstructions: Islands, Part II, ed. S. Harper and D. Zeller, 73-84. University of British Columbia: Fisheries Centre Research.

McClanahan, T., E.H. Allison, and J.E. Cinner. 2015. Managing fisheries for human and food security. Fish and Fisheries 16: 78-103.

Napier, V.R., G.M. Branch, and J.M. Harris. 2005. Evaluating conditions for successful co-management of subsistence fisheries in KwaZulu-Natal, South Africa. Environmental Conservation 32: 165-177.

Nunan, F. 2010. Governance and fisheries co-management on Lake Victoria: challenges to the Adaptive Governance Approach. Maritime Studies 9(1): 103-125.

Nunan, F. 2014. Wealth and welfare? Can fisheries management succeed in achieving multiple objectives? a case study of lake Victoria, East Africa. Fish and Fisheries 15: 134-150.

Ommer, R.E., and team. 2007. Coasts under stress, Restructuring and social-ecological health. Montreal: McGill-Queens University Press. 
Pauly, D. 2014. Small scale fisheries: a global reassessment of their catches, Paper presented at the $2^{\text {nd }}$ World Small Scale Fisheries Congress (WSFC), 20-26. Merida: World Small Scale Fisheries Congress.

Penn, A., and M. Weinstein. 2003. Aboriginal and treaty rights, and subsistence fisheries, Workshop backgrounders: 2003 ocean management research network (OMRN) national conference. Ottawa: Ocean Management Research Network.

Russell, S., C.A. Sullivan, and A.J. Reichelt-Brushett. 2015. Aboriginal consumption of estuarine food resources and potential implications for health through trace metal exposure; a study in gumbaynggirr country, Australia. PLoS ONE 10(6), e0130689.

Sen, A. 1981. Poverty and famines: an essay on entitlement and deprivation. Oxford: Clarendon.

Sowman, M. 2006. Subsistence and small-scale fisheries in South Africa: A ten-year review. Marine Policy 30: 60-73.

Sowman, M., and P. Cardoso. 2010. Small-scale fisheries and food security strategies in countries in the Benguela Current large Marine Ecosystem (BCLME) region: Angola, Namibia and South Africa. Marine Policy 34: 1163-1170.

Statistics Canada. 2013. Norway House Cree Nation, Indian band area, Manitoba (Code 630278) (table), National Household Survey (NHS) Aboriginal Population Profile. 2011 Census. Ottawa: Statistics Canada Catalogue. http:// www12.statcan.gc.ca/nhs-enm/2011/dp-pd/aprof/index.cfm?Lang=E.

Tough, F. 1984. The establishment of a commercial fishing industry and the demise of native fisheries in northern Manitoba. Canadian Journal of Native Studies 4: 303-319.

Tough, F. 1996. As their natural resources fail. Vancouver: University of British Colombia Press.

Trosper, R. 2009. Resilience, reciprocity and ecological economics, Northwest coast sustainability. New York and London: Routledge.

Weeratunge, N., C. Béné, R. Siriwardane, A. Charles, D. Johnson, E.H. Allison, P.K. Nayak, and M.C. Badjeck. 2014. Small-scale fisheries through the wellbeing lens. Fish and Fisheries 15: 255-279.

Zeller, D., S. Harper, K. Zylich, and D. Pauly. 2014. Synthesis of underreported small-scale fisheries catch in Pacific island waters. Coral Reefs. doi:10.1007/s00338-014-1219-1.

\section{Submit your manuscript to a SpringerOpen ${ }^{\circ}$} journal and benefit from:

- Convenient online submission

- Rigorous peer review

- Immediate publication on acceptance

- Open access: articles freely available online

- High visibility within the field

- Retaining the copyright to your article

Submit your next manuscript at $\boldsymbol{\nabla}$ springeropen.com 